\title{
Hubungan paparan bising dengan hipertensi pada karyawan pabrik industri kabel
}

\author{
Nabilla Damar Sukma Andjani, ${ }^{1}$ Dian Mediana ${ }^{2}$
}

\begin{abstract}
ABSTRAK
\section{LATAR BELAKANG}

Hipertensi didefinisikans jika tekanan darah sistolik $\geq 140 \mathrm{mmHg}$ atau tekanan darah diastolik $\geq 90 \mathrm{mmHg}$. RISKESDAS 2018 menunjukkan prevalensi hipertensi di Indonesia adalah $34.11 \%$. Hipertensi merupakan risiko kesehatan umum pada pekerja yang terpapar kebisingan keras $(\geq 85 \mathrm{~dB}(\mathrm{~A}))$. Frekuensi, intensitas, durasi paparan, tipe bising dapat mengganggu aktivitas tubuh seperti sistem pendengaran dan nonpendengaran. Hipertensi merupakan penyakit multi-faktorial yang dapat dipicu dari berbagai sumber seperti paparan bising. Tujuan penelitian ini untuk mengetahui hubungan antara paparan bising dan hipertensi.

\section{METODE}

Penelitian ini dilakukan menggunakan metode analitik observasional dengan pendekatan potong lintang pada 78 responden laki-laki berusia 22-53 tahun di pabrik kabel, Jawa Barat. Data dikumpulkan dengan kuesioner sosiodemografi, sphygmomanometer, microtoise, dan timbangan berat badan. Variabel yang diteliti adalah hipertensi, intensitas bising, tipe bising, masa kerja, usia, jumlah konsumsi rokok. Analisis data menggunakan uji Chi-square dan Kolmogorov-Smirnov dengan $\mathrm{p}<0.05$.
\end{abstract}

\section{HASIL}

Tekanan darah normal 23.1\%, prehipertensi 39.7\%, hipertensi 37.1\%. Intensitas bising $<85 \mathrm{~dB}(\mathrm{~A}) 32.1 \%, \geq 85 \mathrm{~dB}(\mathrm{~A}) 67.9 \%$. Tipe bising kontinu + intermittent $93.6 \%$, impulsif $6.4 \%$. Masa kerja $<10$ tahun $23.1 \%, \geq 10$ tahun $76.9 \%$. Tidak merokok $35.9 \%$, merokok $1-10$ batang $24.4 \%,>10$ batang 39.7\%. Hubungan bermakna antara intensitas bising dan usia dengan hipertensi $(p=0.007 ; p=0.019)$. Hubungan tidak bermakna antara tipe bising, masa kerja, dan konsumsi rokok dengan hipertensi $(\mathrm{p}=0.281$; $\mathrm{p}=0.139 ; \mathrm{p}=0.257)$.

\section{KESIMPULAN}

Terdapat hubungan bermakna antara intensitas bising dan usia dengan hipertensi pada karyawan pabrik industri kabel, namun tidak didapatkan hubungan bermakna antara tipe bising, masa kerja, dan jumlah konsumsi rokok dengan hipertensi.

Kata kunci: hipertensi, paparan bising, usia, intensitas bising, tipe bising

\author{
${ }^{1}$ Program Studi Pendidikan Dokter, \\ Fakultas Kedokteran Universitas \\ Trisakti, Jakarta, Indonesia \\ ${ }^{2}$ Departemen Anatomi, Fakultas \\ Kedokteran Universitas Trisakti, \\ Jakarta, Indonesia \\ Korespondensi: \\ Dian Mediana \\ Departemen Anatomi, Fakultas \\ Kedokteran Universitas Trisakti, \\ Jakarta, Indonesia \\ Jalan Kyai Tapa (Kampus B) \\ Usakti, Grogol, Indonesia 11440 \\ Email: dianmediana@trisakti.ac.id
}

J Biomedika Kesehat 2021;4(2):57-64 DOI: 10.18051/JBiomedKes.2021. v4.57-64

pISSN: 2621-539X / eISSN: 2621-5470

Artikel akses terbuka (open access) ini didistribusikan di bawah lisensi Creative Commons Attribution 4.0 International (CC-BY 4.0) 


\section{ABSTRACT}

\section{Relationship between noise exposure and hypertension in cable industry factory employees}

\section{BACKGROUND}

Hypertension defined as systolic blood pressure $\geq 140 \mathrm{mmHg}$ or diastolic blood pressure $\geq 90 \mathrm{mmHg}$. RISKESDAS 2018 shows the prevalence of hypertension in Indonesia is $34.11 \%$. Hypertension is a common health risk for workers exposed to loud noise $(\geq 85 \mathrm{~dB}(\mathrm{~A}))$. Frequency, intensity, duration of exposure, type of noise can interfere with body activities: auditory and non-auditory systems. Hypertension is a multi-factor disease that can be triggered from various sources such as noise exposure. This study aims to knowing the relationship between noise exposure and hypertension.

\section{METHODS}

Using an observational analytic method with cross-sectional approach which included 78 male respondents from 22-53 years at cable factory in West Java. The data collection tools were sociodemographic questionnaires, sphygmomanometer, microtoise, weight scales. The variables studied were hypertension, noise intensity, type of noise, work period, age, number of cigarette consumption. Data analysis used the Chi-square and KolmogorovSmirnov test with $\mathrm{p}<0.05$.

\section{RESULTS}

Normal blood pressure $23.1 \%$, prehypertension 39.7\%, hypertension 39.7\%. Noise intensity $<85 \mathrm{~dB}$ (A) $32.1 \%$, $\geq 85 \mathrm{~dB}$ (A) $67.9 \%$. Type of continuous noise + intermittent $93.6 \%$, impulsive $6.4 \%$. Work period $<10$ years $23.1 \%$, $\geq 10$ years $76.9 \%$. Workers do not smoke $35.9 \%$, smoke $1-10$ cigarettes $24.4 \%,>10$ cigarettes $39.7 \%$. There was a significant relationship between noise intensity and age with hypertension $(p=0.007 ; p=0.019)$. There was no significant relationship between the type of noise, years of service, and the number of cigarette consumption with hypertension $(p=0.281 ; p=0.139 ; p=0.257)$.

\section{CONCLUSION}

There was a significant relationship between noise intensity and age with hypertension. There was no significant relationship between the type of noise, years of service, and the number of cigarette consumption with hypertension.

Keywords: hypertension, noise exposure, age, noise intensity, type of noise

\section{PENDAHULUAN}

WHO memperkirakan bahwa sekitar 250 juta pekerja di seluruh dunia terpapar dengan tingkat kebisingan yang berpotensi bahaya. ${ }^{(1)}$ Tingkat paparan kebisingan kerja yang tinggi $(>85$ dB) menimbulkan risiko yang signifikan terhadap kesehatan dan keselamatan kerja. ${ }^{(2)}$ Hipertensi merupakan salah satu risiko kesehatan umum di antara para pekerja yang terpapar kebisingan keras. Hipertensi atau tekanan darah tinggi adalah kondisi medis yang berkepanjangan di mana tekanan darah di arteri terus meningkat. Menurut WHO disebut hipertensi bila tekanan darah sistolik $\geq 140 \mathrm{mmHg}$ atau tekanan darah diastolik $\geq 90 \mathrm{mmHg}$, atau yang telah dirawat karena hipertensi. ${ }^{(1)}$ Sebuah penelitian yang dilakukan di Zhengzhou, China pada 3.150 pekerja pabrik baja menunjukkan prevalensi hipertensi sebesar $29.88 \%$ pada lakilaki dan $12.13 \%$ pada perempuan yang terpapar dengan tingkat kebisingan kumulatif $95 \mathrm{~dB}$ hingga $113 \mathrm{~dB}^{(3)}$ Hasil penelitian pada tahun 2014-2015 mengenai prevalensi hipertensi (yang disesuaikan berdasarkan usia) pada orang dewasa di Indonesia yaitu sebesar 33.4\% pada kelompok usia 18 tahun atau lebih dan $48.6 \%$ pada usia 40 tahun atau lebih.
(4) Paparan bising dapat dikaitkan dengan penyakit kardiovaskular, seperti penyakit jantung iskemik, infark miokard, penyakit jantung koroner, dan stroke. Penelitian Chang TY menunjukkan bahwa pekerja laki-laki yang terpapar dengan tingkat kebisingan $\geq 85 \mathrm{~dB}(\mathrm{~A})$ dan menggunakan alat pelindung telinga mengalami peningkatan ratarata tekanan darah sistolik sebesar $3.2 \quad(95 \%$ CI: $0.2 ; 6.2) \mathrm{mmHg}$. Mereka juga mengalami peningkatan tekanan darah diastolik $2.5(95 \%$ CI: 0.1 ; 4.8) $\mathrm{mmHg}$ antara pengukuran awal dan pengukuran lanjut. Temuan ini memberikan bukti adanya hubungan antara paparan kebisingan di atas $85 \mathrm{~dB}(\mathrm{~A})$ dan risiko hipertensi yang lebih tinggi. ${ }^{(5)}$ Penelitian Siswati et al. mendapatkan perbedaan yang bermakna antara tekanan darah sistolik dan diastolik sebelum dan sesudah bekerja pada pekerja industri kemasan semen yang terpapar kebisingan sebesar $>85 \mathrm{~dB}{ }^{(6)}$

Namun, penelitian lain menunjukkan perbedaan bahwa tidak mendapatkan hubungan antara paparan kebisingan di tempat kerja dengan insiden hipertensi. Selain itu, model multivariat yang digunakan (usia, indeks massa tubuh, riwayat merokok, nilai pendengaran awal, ambang batas, kehilangan ambang pendengaran dalam tahunan 
rata-rata, dan upah tahunan) gagal menunjukkan hubungan antara tingkat ambang pendengaran awal atau perubahan tahunan dalam tingkat ambang pendengaran dengan risiko hipertensi. Meskipun demikian, mungkin dapat diperkirakan bahwa penurunan paparan kebisingan akibat gangguan pendengaran dapat memengaruhi risiko hipertensi. Penelitian tersebut menetapkan gangguan pendengaran sebagai prediktor utama mereka. ${ }^{(7)}$ Maka dari itu, peneliti membuat penelitian ini untuk mengetahui apakah ada hubungan dalam paparan bising dengan hipertensi pada pekerja industri kabel.

\section{METODE}

Penelitian ini dilakukan dengan menggunakan metode analitik observasional dengan pendekatan cross sectional. Penelitian ini dilakukan di pabrik kabel PT.X yang beroperasi di Jawa Barat. Populasi pada penelitian ini adalah seluruh pekerja yang bekerja di unit produksi pada pabrik kabel PT. X yang terpapar bising saat bekerja dan memenuhi kriteria. Sampel dipilih dengan metode probability sampling, yaitu stratified random sampling dengan jumlah sampel sebanyak 78 pekerja. Penelitian dimulai dengan menentukan sub-populasi dari pekerja, lalu mengukur kebisingan pada mesin yang terdapat pada tiap-tiap station kerja menggunakan sound level meter dengan pengukuran sewaktu yang diukur sepuluh menit untuk tiap titik pengukuran yang mewakili letak mesin dan posisi operator mesin, pembacaan dilakukan selama lima detik. Setelah bekerja, pekerja diminta untuk beristirahat terlebih dahulu tanpa konsumsi kafein dan rokok selama 30 menit sebelum pemeriksaan. Dilakukan pengukuran terhadap tinggi badan dan berat badan untuk menghitung indeks massa tubuh serta pemeriksaan tekanan darah menggunakan sphygmomanometer dengan pembacaan pada lengan kanan dan kiri. Sebelumnya responden sudah menandatangani informed consent. Hasil akan dituangkan pada kuesioner sosiodemografi. Kriteria inklusi pada penelitian ini adalah pekerja pada PT.X yang sudah bekeja minimal 1 tahun. Kriteria eksklusi penelitian ini adalah pekerja yang memiliki riwayat hipertensi 5 tahun terakhir, memiliki riwayat hipertensi pada keluarga, mengonsumsi obat yang memengaruhi tekanan darah, memiliki riwayat penyakit ginjal, kardiovaskular, diabetes dan penyakit kronik lainnya, obesitas, merokok lebih dari 11-12 batang/hari.

Analisis data yang dilakukan adalah univariat dengan memaparkan hasil distribusi frekuensi dan persentase dari setiap variabel. Analisis bivariat dilakukan untuk melihat hubungan antara variabel bebas dengan variabel terikat menggunakan uji Chi-square dan Kolmogorov-Smirnov dengan tingkat kemaknaan adalah $<0.05$. Penelitian ini telah memperoleh ethical clearance dari Komisi Etik Penelitian Fakultas Kedokteran Universitas Trisakti dengan Nomor 62/KER-FK/10/2020.

\section{HASIL}

Penelitian ini dilakukan terhadap karyawan pabrik industri kabel PT. X yang beroperasi di Jawa Barat, dengan jumlah sampel sebanyak 78 responden dan terpenuhi.

Tabel 1. Distribusi frekuensi usia, tekanan darah, intensitas dan tipe bising, lama masa kerja, dan konsumsi rokok $(\mathrm{n}=\mathbf{7 8})$

\begin{tabular}{lcc}
\hline Distribusi frekuensi & $\mathbf{n}$ & $\mathbf{\%}$ \\
\hline Karakteristik responden & & \\
Usia & & \\
$<40$ tahun & 43 & 55.1 \\
$\geq 40$ tahun & 35 & 44.9 \\
Tekanan darah & & \\
Normal & 18 & 23.1 \\
Prehipertensi & 31 & 39.7 \\
Hipertensi 1 & 20 & 25.6 \\
Hipertensi 2 & 9 & 11.5 \\
Intensitas bising & & \\
$<85$ dB(A) & 25 & 32.1 \\
$\geq 85$ dB(A) & 53 & 67.9 \\
Tipe bising & & \\
Kontinu & 10 & 12.8 \\
Intermittent & 63 & 80.8 \\
Impulsif & 5 & 6.4 \\
Lama masa kerja & & \\
$<10$ tahun & 18 & 23.1 \\
$\geq 10$ tahun & 60 & 76.9 \\
Konsumsi rokok & & \\
Tidak merokok & 28 & 35.9 \\
$1-10$ batang & 19 & 24.4 \\
$>10$ batang & 31 & 39.7 \\
\hline Ke &
\end{tabular}

Keterangan: $n=$ jumlah; $\%=$ persentase 
Tabel 2. Hubungan intensitas dan tipe bising, lama masa kerja, usia, dan jumlah konsumsi rokok dengan hipertensi pada karyawan pabrik industri kabel $(n=78)$

\begin{tabular}{|c|c|c|c|c|c|c|c|c|c|}
\hline \multirow{3}{*}{ Variabel bebas } & \multicolumn{9}{|c|}{ Tekanan darah } \\
\hline & \multicolumn{2}{|c|}{ Normal } & \multicolumn{2}{|c|}{ Prehipertensi } & \multicolumn{2}{|c|}{ Hipertensi } & \multicolumn{2}{|c|}{ Total } & \multirow[t]{2}{*}{ Nilai $p$} \\
\hline & $\mathbf{n}$ & $\%$ & $\mathbf{n}$ & $\%$ & $\mathbf{n}$ & $\%$ & $\mathbf{n}$ & $\%$ & \\
\hline \multicolumn{10}{|l|}{ Intensitas bising } \\
\hline$<85 \mathrm{~dB}(\mathrm{~A})$ & 8 & 32 & 14 & 56 & 3 & 12 & 25 & 100 & \multirow{2}{*}{$0.007^{\#}$} \\
\hline$\geq 85 \mathrm{~dB}(\mathrm{~A})$ & 10 & 18.9 & 17 & 32.1 & 26 & 49.1 & 53 & 100 & \\
\hline \multicolumn{10}{|l|}{ Tipe bising } \\
\hline Kontinu & 18 & 24.7 & 30 & 41.1 & 25 & 34.2 & 73 & 100 & \multirow{2}{*}{$0.281^{*}$} \\
\hline Impulsif & 0 & 0 & 1 & 20 & 4 & 80 & 5 & 100 & \\
\hline \multicolumn{10}{|l|}{ Lama masa kerja } \\
\hline$<10$ tahun & 7 & 38.9 & 7 & 38.9 & 4 & 22.2 & 18 & 100 & \multirow{2}{*}{$0.139^{\#}$} \\
\hline$\geq 10$ tahun & 11 & 18.3 & 24 & 40 & 25 & 41.7 & 60 & 100 & \\
\hline \multicolumn{10}{|l|}{ Usia } \\
\hline$<40$ tahun & 12 & 27.9 & 21 & 48.8 & 10 & 23.3 & 43 & 100 & \multirow{2}{*}{$0.019^{\#}$} \\
\hline$\geq 40$ tahun & 6 & 17.1 & 10 & 28.6 & 19 & 54.3 & 35 & 100 & \\
\hline \multicolumn{10}{|l|}{ Jumlah Konsumsi Rokok } \\
\hline Tidak merokok & 9 & 32.1 & 10 & 35.7 & 9 & 32.1 & 28 & 100 & \multirow{3}{*}{$0.257^{\#}$} \\
\hline 1-10 batang & 2 & 10.5 & 11 & 57.9 & 6 & 31.6 & 19 & 100 & \\
\hline$>10$ batang & 7 & 22.6 & 10 & 32.3 & 14 & 45.2 & 31 & 100 & \\
\hline
\end{tabular}

\# uji Chi-square

* uji Kolmogorov-Smirnov

Dari 78 responden yang berusia dari $22-53$ tahun, usia terbanyak adalah 39 tahun yaitu $14.1 \%$ responden. Kategori tekanan darah terbanyak pada kelompok prehipertensi yaitu sebesar 39.7\%. Responden yang terpapar bising $\geq 85 \mathrm{~dB}(\mathrm{~A})$ (85$100.1 \mathrm{~dB})$ sebanyak $67.9 \%$. Tipe bising yang didapatkan dalam penelitian ini didominasi oleh tipe intermitten sebanyak $80.8 \%$ dari berbagai mesin produksi. Kebisingan tipe intermitten tertinggi adalah $95 \mathrm{~dB}(\mathrm{~A})$ yaitu pada proses wire drawing. Sebanyak 10 (12.8\%) responden terpapar bising tipe kontinu, dan hanya 5 (6.4\%) responden yang terpapar tipe bising impulsif dengan intensitas bising mencapai $100.1 \mathrm{~dB}(\mathrm{~A})$. Lebih banyak responden yang telah bekerja $\geq 10$ tahun (10-24 tahun) dibandingkan dengan yang kurang dari 10 tahun yaitu $76.9 \%$ dan $23.1 \%$. Kebiasaan konsumsi rokok pada penelitian ini didapatkan bahwa responden memiliki kebiasaan merokok $>10$ batang/hari (11-12 batang) dengan jumlah reponden sebanya 31 (39.7\%) responden.

Intensitas bising yang didapatkan dalam penelitian ini mulai dari kategori $<85 \mathrm{~dB}(\mathrm{~A})$ dari 77.9-84.3 dB(A), terdapat sebanyak 25 (32.,1\%) responden yang berkerja dalam kebisingan
$<85 \mathrm{~dB}(\mathrm{~A})$. Kebisingan paling rendah terletak pada operator forklift 10 Ton. Sedangkan untuk kebisingan $\geq 85 \mathrm{~dB}(\mathrm{~A})$ dari $85-100.1 \mathrm{~dB}(\mathrm{~A})$, terdapat $53(67.9 \%)$ responden yang berkerja dalam kebisingan $\geq 85 \mathrm{~dB}(\mathrm{~A})$. Kebisingan tertinggi terdapat pada bagian pekerjaan packaging, menggunakan alat gunshot dengan kebisingan $100.1 \mathrm{~dB}(\mathrm{~A})$.

Pada intensitas bising $<85 \mathrm{~dB}(\mathrm{~A})$, kebanyakan responden memiliki tensi normal dan prehipertensi. Pada intensitas bising yang tinggi $\geq 85 \mathrm{~dB}(\mathrm{~A})$ terdapat paling banyak responden yang menderita hipertensi. Dengan menggunakan uji Chi-square didapatkan hasil hubungan yang bermakna antara intensitas bising dengan kejadian hipertensi $(\mathrm{p}=0.007)$.

Responden dengan lama masa kerja $<10$ tahun lebih banyak yang memiliki tensi normal dan prehipertensi, sedangkan mereka yang sudah bekerja $\geq 10$ tahun lebih banyak yang menderita hipertensi stadium 1 dan 2. Dengan menggunakan uji Chi-square didapatkan nilai $\mathrm{p}=0.139$ berarti tidak terdapat hubungan yang bermakna antara lama masa kerja dengan hipertensi. Responden yang berusia $<40$ tahun lebih banyak yang memiliki 
tensi normal dan prehipertensi, sedangkan yang berusia $\geq 40$ tahun lebih banyak yang menderita hipertensi stadium 1 dan 2. Dengan menggunakan uji Chi-square didapatkan hubungan yang bermakna antara usia dengan hipertensi $(\mathrm{p}=0.019)$. Konsumsi rokok pada penelitian ini didominasi oleh kelompok merokok $>10$ batang (11-12 batang/hari) sebanyak 31 (39.7\%) responden dengan prevalensi hipertensi sebanyak $45.2 \%$, dan prehipertensi sebanyak 32.3\%. Pada kelompok 1-10 batang/hari 19 (24.4\%) responden memiliki prevalensi hipertensi $31.6 \%$, prehipertensi $57.9 \%$. Pada 28 (35.9\%) responden yang tidak merokok memiliki prevalensi hipertensi $32.2 \%$, angka ini sedikit lebih tinggi dari responden yang merokok 1-10 batang/hari. Pada variabel konsumsi rokok dengan hipertensi tidak didapatkan hasil yang dominan. Dengan menggunakan metode analisis Chi-square didapatkan nilai $\mathrm{p}=0.257$, tidak terdapat hubungan yang bermakna antara konsumsi rokok dengan hipertensi. Bising tipe intermittent dengan kontinu sudah melewati tahap uji gabung sel, karena penyebaran data yang tidak memenuhi expected count dari syarat Chi-square. Dianalisis dengan menggunakan uji KolmogorovSmirnov didapatkan Sig. 0.281 ( $>0.05)$, berarti tidak terdapat hubungan bermakna antara tipe bising dengan kejadian hipertensi.

\section{PEMBAHASAN}

Pabrik ini hanya mempekerjakan operator yang berjenis kelamin laki-laki saja dengan berbagai kelompok usia, pada analisis frekuensi terbanyak didapatkan pada usia dewasa akhir dengan rata-rata usia 39 tahun (mean 38.69; SD 6.61). Didapatkan bahwa usia memiliki hubungan yang bermakna terhadap risiko terjadinya hipertensi, $\mathrm{p}=0.019$. Penelitian oleh Attarchi M et al. menunjukkan bahwa prevalensi hipertensi memang dapat meningkat baik pada usia tua, pengalaman kerja yang tinggi, merokok, pola makan yang tinggi garam dan juga olahraga tidak teratur. $^{(8)}$ Prevalensi hipertensi lebih sedikit pada wanita dibandingkan pria hingga usia 45 tahun, dan serupa pada kedua jenis kelamin dari usia 45 hingga 64 tahun. ${ }^{(9)}$ Hal tersebut sesuai dengan hasil penelitian ini, pada penelitian ini didapatkan prevalensi hipertensi pada pria meningkat pada usia $\geq 40$ tahun (54.3\%). Hal ini sejalan dengan penelitian Harianto E ${ }^{(10)}$ dan de Souza et al. ${ }^{(11)}$
Kemungkinan risiko kejadian hipertensi pada usia $\geq 40$ tahun disebabkan oleh perubahan alami pada jantung, pembuluh darah, dan hormon. ${ }^{(10)}$

Hubungan antara intensitas bising dengan hipertensi pada kelompok yang terpapar kebisingan $\geq 85 \mathrm{~dB}(\mathrm{~A})$ memiliki risiko mengalami hipertensi lebih tinggi daripada kelompok kebisingan $<85 \mathrm{~dB}(\mathrm{~A})$ (OR 2.02). Analisis statistik Chisquare didapatkan nilai $\mathrm{p}=0.007$ dinilai memiliki hubungan yang bermakna antara intensitas bising dengan hipertensi. Hal ini didukung penelitian de Souza et al. (2015) bahwa pekerja yang terpajan pada tingkat kebisingan $\geq 85 \mathrm{~dB}(\mathrm{~A})$ dan mereka yang terpapar pada tingkat yang bervariasi dari 75$85 \mathrm{~dB}(\mathrm{~A})$ menunjukkan kemungkinan 60\% (OR 1.56) lebih tinggi untuk mengalami tekanan darah tinggi $(\mathrm{p}=0.002) .{ }^{(11)}$ Kebisingan dianggap sebagai penyebab stres biologis yang tidak spesifik. Stres yang disebabkan oleh tingkat kebisingan yang tinggi meningkatkan pelepasan adrenalin, menyempitkan pembuluh darah perifer, dan akhirnya menyebabkan hipertensi. ${ }^{(12)}$ Kebisingan juga dapat menyebabkan gangguan saraf vegetatif, menyebabkan pelepasan mediator proinflamasi. Sitokin proinflamasi (IL-17, ICAM-1, IL-6, TNFa) populasi leukosit aktif dan disfungsi endotel yang disebabkan oleh stres oksidatif terlibat dalam pengembangan hipertensi. ${ }^{(13,14)}$ Prevalensi dan insiden penyakit seperti kardiovaskular dan kematian diketahui lebih tinggi pada kelompok yang terpapar kebisingan. ${ }^{(15)}$

Tipe bising dan tekanan darah tidak memiliki hubungan yang bermakna, dengan uji Kolmogorov-Smirnov didapatkan nilai $\mathrm{p}=0.281$. Tidak terdapatnya hubungan yang bermakna pada hasilinikarenapekerjayangterpaparbisingimpulsif hanya sebagian kecil $(0.006 \%)$ dibandingkan yang terpapar bising kontinu atau pun intermittent. Diungkapkan Khoirunnisa N et al., kebisingan tipe kontinu dan intermittent meningkatkan perubahan tekanan darah dan dapat menyebabkan hipertensi. Dibuktikan dengan meningkatnya tekanan darah pada kebisingan tipe kontinu dan intermittent pada intensitas $>80 \mathrm{~dB}(\mathrm{~A})$. Saat terpapar bising, terdapat jalur 'direct' ditentukan oleh interaksi sesaat dari saraf pendengaran dengan berbagai struktur sistem saraf pusat, sensasi tersebut dirasakan oleh sensor pendengaran. ${ }^{(16)} \mathrm{Hal}$ ini menyebabkan hiperaktivitas HPA axis yang berakibat disregulasi dari HPA Axis. ${ }^{(2,15,16)}$ Jalur 
'indirect' mengacu pada persepsi kognitif suara, aktivasi kortikal dan respons emosional terkait. ${ }^{(15)}$ Paparan dan pengulangan terus menerus terhadap kebisingan dapat bersifat patogen, mengarah pada peningkatan regulasi auto vaskular yang persisten yang mengakibatkan hipertensi. ${ }^{(1)}$ Diketahui bahwa kebisingan impulsif memang jauh lebih berbahaya daripada kebisingan bersifat kontinu. ${ }^{(17)}$ Studi prospektif Skotsgad et al. pada pekerja industri dengan paparan bising $>80 \mathrm{~dB}(\mathrm{~A})$ dalam kombinasi dengan kebisingan impulsif menunjukkan bahwa pada pekerja ditemukan peningkatan risiko penyakit kardiovaskular yang menetap, bahkan setelah pekerja pensiun. ${ }^{(18)}$

Kecenderungan hipertensi meningkat sesuai dengan lama masa kerja, namun dengan analisis statistika didapatkan nilai $\mathrm{p}=0.139$ ( $\mathrm{p}>$ 0.05 ), dinilai tidak memiliki hubungan yang bermakna. Hal ini didukung oleh penelitian sebelumnya yang menyatakan lama masa kerja tidak memiliki hubungan yang bermakna dengan kejadian hipertensi $(\mathrm{p}=0.25) .{ }^{(10)}$ Bertolak belakang dengan studi yang dilakukan oleh Shresta A et al., menyatakan bahwa lama masa kerja berkorelasi positif dengan terjadinya hipertensi $(\mathrm{p}=0.03) .{ }^{(1)}$ de Souza et al. mengamati bahwa paparan kebisingan $\geq 85 \mathrm{~dB}$ selama $>10$ tahun berhubungan dengan hipertensi $\mathrm{i}^{(11)}$ dan Wang et al. menyatakan risiko hipertensi secara signifikan lebih tinggi pada kelompok paparan kebisingan $\geq 20$ tahun. ${ }^{(19)}$ Paparan bising kronis dan berulang dapat menyebabkan ketidakseimbangan dalam homeostasis yang memengaruhi metabolisme dan sistem kardiovaskular, dengan peningkatan faktor risiko penyakit kardiovaskular seperti tekanan darah, konsentrasi lipid darah, viskositas darah, dan konsentrasi glukosa darah. Perubahanperubahan ini meningkatkan risiko hipertensi. ${ }^{(20)}$ Namun, terdapat kemungkinan dengan tekanan darah yang meningkat akut pada penelitian ini dengan responden lama masa kerja $<10$ tahun jika tekanan tersebut berulang dan aktivasi sistem saraf simpatis yang menyertainya, atau hiperresponsif terhadap stres. Peningkatan paparan bising yang bersifat akut dalam jumlah besar yang disebabkan oleh aktivasi sistem saraf simpatis yang di induksi oleh stres dapat menyebabkan cedera kecil pada jaringan target, terutama ginjal, yang jika menumpuk dari waktu ke waktu menyebabkan hipertensi kronis. ${ }^{(21)}$
Padapenelitian ini usiamemiliki hubungan yang bermakna terhadap risiko terjadinya hipertensi, $\mathrm{p}=0.019$. Beberapa faktor yang dapat menyebabkan bahwa usia berkorelasi dengan hipertensi dikarenakan dengan bertambahnya usia, maka fungsi tubuh pun akan mengalami perubahan pada fungsi fisiologisnya. Diketahui bahwa arteri menunjukkan 2 perubahan fisik utama seiring bertambahnya usia. Mereka mengalami dilatasi dan kaku. Hal ini menyebabkan arteri yang kaku mengalami penurunan kapasitansi dan recoil yang terbatas sehingga tidak dapat mengakomodasi perubahan yang terjadi selama siklus jantung. Selain itu, mekanisme neurohormonal seperti sistem renin-angiotensin-aldosteron menurun seiring bertambahnya usia. Aktivitas sistem saraf simpatis akan meningkat sesuai bertambahnya usia. Konsentrasi norepinefrin plasma perifer pada orang tua ditemukan dua kali lipat dari tingkat subjek yang lebih muda. ${ }^{(9)}$

Konsumsi rokok dan hipertensi tidak memiliki hubungan yang bermakna, nilai $\mathrm{p}=0.257$. Temuan ini didukung oleh penelitian Harianto yang mengatakan bahwa kebiasaan merokok tidak memiliki nilai yang bermakna $(p=0.27)$ dengan terjadinya hipertensi. Sejatinya, nikotin pada rokok secara langsung akan meningkatkan tekanan darah. Efek peningkatan tekanan darah memang sementara, sekitar 30 menit selama seseorang merokok. ${ }^{(10)}$ Merokok menyebabkan aktivasi simpatis, stres oksidatif, dan efek vasopresor akut yang berhubungan dengan peningkatan penanda oksidatif peradangan yang terkait dengan hipertensi. ${ }^{(22)}$ Ada kemungkinan bahwa dampak penggunaan tembakau saat ini terhadap hipertensi tertunda dan karenanya penggunaan tembakau saat ini mungkin tidak berkorelasi erat dengan hipertensi. ${ }^{(4)}$ Penelitian ini memiliki beberapa keterbatasan, yaitu kurangnya variasi dari variabel penelitian seperti halnya tipe bising yang ditemukan didominasi oleh tipe intermittent. Hipertensi merupakan penyakit multi-factorial yang menyebabkan kemungkinan banyak pengaruh lain selain dari variabel yang diteliti. Pekerja tidak selamanya berdiam diri di sekitar mesin, cenderung berpindah-pindah atau berkeliling. 


\section{KESIMPULAN}

Hasil pengukuran tekanan darah responden menunjukkan $39.7 \%$ termasuk prehipertensi, $25.6 \%$ termasuk hipertensi stadium $1,23.1 \%$ tensi normal, dan $11.5 \%$ hipertensi stadium 2 . Terdapat hubungan yang bermakna antara intensitas bising dan usia dengan hipertensi. Tidak terdapat hubungan yang bermakna antara tipe bising, lama masa kerja dan konsumsi rokok dengan hipertensi.

Peneliti menyarankan agar pekerja untuk patuh menggunakan APD berupa alat pelindung pendengaran, earmuffs, earplugs, dan ear canal caps. Pemakaian yang tidak konsisten akan mengurangi efektivitas dari efek pelindung telinga Jika paparan kebisingan berdasarkan waktu pekerja melebihi $100 \mathrm{~dB}(\mathrm{~A})$, earplug dan earmuffs dipakai. Penting untuk dicatat bahwa menggunakan proteksi ganda seperti itu hanya akan menambah redaman 5 sampai $10 \mathrm{~dB}$. Pengawas harus secara berkala memastikan bahwa pelindung pendengaran dipakai, dipasang dengan benar, dan sesuai untuk kebisingan saat dikenakan. Pemantauan kebisingan dengan penekanan pada karakterisasi paparan kebisingan berdasarkan prinsip model penilaian eksposur berbasis tugas (T-BEAM) sangat cocok untuk pekerja yang berpindah-pindah atau keliling.

Penelitian selanjutnya disarankan memperluas populasi serta memperbanyak responden. Sehingga, hasil penelitian yang diperoleh dapat lebih akurat. Menambah variabel lain seperti shift kerja, profil lipid, dan respon stres. Studi kohort atau case control dianjurkan untuk mengecek hormon stres serta meneliti respon stres. Pengukuran bising disarankan dengan menggunakan alat ukur kebisingan portabel digunakan untuk menentukan kebisingan yang dibawa oleh setiap pekerja (personal dosimeter) dalam jam kerja mereka dikarenakan pekerja cenderung berpindah-pindah. Metode pengukuran 8 jam kerja dianjurkan karena bisa saja ada perbedaan dengan pengukuran dengan metode sewaktu. Penelitian mengenai tipe bising diperlukan untukmenentukan parameterberbahaya dari kebisingan impulsif dan keterkaitannya. Parameter ini harus mencakup amplitudo, durasi, waktu naik, jumlah impuls, laju pengulangan, dan faktor puncak.

\section{UCAPAN TERIMA KASIH}

Pihak pabrik industri kabel di Kawasan Industri, Cikampek, Jawa Barat.

\section{KONFLIK KEPENTINGAN}

Semua peneliti tidak memiliki konflik kepentingan terhadap hasil penelitian ini.

\section{REFERENSI}

1. Shrestha A, Shiqi M. Occupational noise exposure in relation to hypertension: a cross-sectional study in the steel factory. Occup Med Health Aff. 2017;5.266:2. doi: 10.4172/2329-6879.1000266

2. Indriyanti LH, Wangi PK, Simanjuntak K. Hubungan paparan kebisingan terhadap peningkatan tekanan darah pada pekerja. JKK. 2019; 15(1):36-45. doi: 10.24853/jkk.15.1.36-45

3. Li YH, Chen GS, Yu SF. Prevalence and influence factors of hypertension among the workers exposed to noise in steel making and steel rolling workshop of an iron and steel plant. Artic Chinese. 2015;49(5):405-10. PMID: 26081703

4. Peltzer K, Pengpid S. The prevalence and social determinants of hypertension among adults in Indonesia: A cross-sectional population-based national survey. Int J Hypertens. 2018; 2018: 5610725. doi: 10.1155/2018/5610725

5. Chang TY, Hwang BF, Liu CS, et al. Occupational noise exposure and incident hypertension in men: a prospective cohort study. Am J Epidemiol. 2013; 177.8: 818-25. doi: 10.1093/aje/kws300

6. Siswati AR, Adriyani R. Hubungan pajanan kebisingan dengan tekanan darah dan denyut nadi pada pekerja industri kemasan semen. Jurnal Kesehatan Lingkungan Indonesia 2017; 16(1): 2936. doi: 10.14710/jkli.16.1.29-36

7. Tessier SB, Galusha D, Cantley LF, et al. Occupational noise exposure and risk of hypertension in an industrial workforce. Am J Ind Med. 2017; 60.12: 1031-8. doi: 10.1002/ ajim. 22775

8. Attarchi M, Dehghan F, Safakhah F, et al. Effect of exposure to occupational noise and shift working on blood pressure in rubber manufacturing company workers. Industrial health $2011 ; 1203250128$. doi: 10.2486/indhealth.MS1321

9. Lionakis N, Mendrinos D, Sanidas E, et al. Hypertension in the elderly. World journal of cardiology 2012; 4(5): 135. doi: 10.4330/wjc. v4.i5.135

10. Harianto E, Pratomo H. Pajanan kebisingan dan hipertensi di kalangan pekerja pelabuhan. Kesmas: National Public Health Journal 2013; 8(5), 215-20. doi: 10.21109/kesmas.v8i5.387

11. Souza TCF, Périssé ARS, Moura M. Noise exposure and hypertension: investigation of a silent relationship. BMC public health 2015; 15(1): 328. doi: $10.1186 / \mathrm{s} 12889-015-1671-\mathrm{z}$

12. Rizi HAY, Dehghan H. Effects of occupational noise exposure on changes in blood pressure of workers. ARYA Atherosclerosis 2013;183-6. doi: $10.1186 / \mathrm{s} 13643-020-01364-\mathrm{Z}$

13. Fu W, Wang C, Zou L, et al. Association between exposure to noise and risk of hypertension: a meta-analysis of observational epidemiological studies. J Hypertens 2017; 35.12: 2358-66. doi: 
10.1097/HJH.0000000000001504

14. Harwani SC, Chapleau MW, Legge KL, et al. Neurohormonal modulation of the innate immune system is proinflammatory in the prehypertensive spontaneously hypertensive rat, a genetic model of essential hypertension. Circ Res 2012; 111: 11907. doi: 10.1161/CIRCRESAHA.112.277475

15. Basner M, Babisch W, Davis A, et al. Auditory and non-auditory effects of noise on health. Lancet 2014; 383(9925): 1325-32. doi.org/10.1016/ S0140-6736(13)61613-X

16. Khoirunnisa N, Nadiroh A, Arifianto D, et al. A pilot study: the impact of continuous and intermittent noise on human blood pressure changes. JPhCS, 2018; 1075(1): 012081. doi:10.1088/17426596/1075/1/012081

17. Nassiri P, Abbasi AM, Poornadjaf A. Occupational noise and blood pressure variation. Lebanese Science Journal 2019; 20(1): 148-60. doi: 10.22453/LSJ-020.1.148-160

18. Skogstad M, Johannessen HA, Tynes T. Systematic review of the cardiovascular effects of occupational noise. Occup Med 2016; 66(1): 10-6. doi.org/10.1093/occmed/kqw113

19. Wang D, Zhou M, Li W, et al. Occupational noise exposure and hypertension: the Dongfeng-Tongji Cohort Study. JASH. 2018; 12.2: 71-9. doi. org/10.1016/j.jash.2017.11.001

20. Babisch W, Pershagen G, Selander J, et al. Noise annoyance - a modifier of the association between noise level and cardiovascular health? Sci Total Environ 2013; 452: 50-7. doi: 10.1016/j. scitotenv.2013.02.034

21. Hall JE, Granger JP, Do CJM, et al. Hypertension: physiology and pathophysiology. Compr Physiol. 2012;2:2393-442. doi: 10.1002/cphy.c110058

22. Zawilla N, Shaker D, Abdelaal A, et al. Angiotensinconverting enzyme gene polymorphisms and hypertension in occupational noise exposure in Egypt. Int J Occup Environ Health. 2014; 20(3): 194-206. doi: 10.1179/2049396714Y.0000000067 